\title{
Of the Possibility of Immanent Revolt as Theory and Political Praxis
}

\section{Katerina Kolozova}

professor of philosophy and feminism at the

Institute of Social Sciences and Humanities - Skopje.

(katerina.kolozova@isshs.edu.mk)

\begin{abstract}
:
The only way to immanently revolt against the world is the non-abstract way. Revolting against concrete occurrences of subjugation and violence rather than in the name of abstractions and visions of transformation of the world is political action "affected by immanence." It is also action determined by "interests" which are real and sensuous (or material), says Marx, rather than abstract or philosophical. According to Marx, abstraction itself is what ought to be combated and a world in consonance with the real or the material immediate exigencies should be created. The world will be always made of philosophy, Laruelle would say, and it will always already persecute the human in human. The constant revolution can transform it into a socio-political order which is observant of the "real interests" rather than abstractions, writes Marx. In that way, the world could become a more just and happier place, one where persecution is minimalised by virtue of the reversal in hierarchy between philosophy and the real whereby the former would succumb to the dictate of the latter.
\end{abstract}

Key words: Marxism, Non-Marxism, the real, abstraction, immanence, victim, persecution

\section{Immanence of revolt}

Revolt is immanent when determined in the last instance by the lived of revolt not by a transcendental moral or political decision of either acting or reacting against another moral or political vision. The experience of revolt void of philosophy precedes language and, therefore, transcendence. The precedence in question is not temporal and the independence from the linguistic does not imply a metaphysically construed separate universe. Namely, the purely experiential or "lived" of revolt can be caused by an act of language which inflicts violence but the reaction is rebellion which is an instantiation of the conatus to stay in life. Activity which increases life is the result of the conatus (to stay in life), says Spinoza in his Ethics, and revolt and struggle aim to maintain or intensify life by combating the life decreasing activity of the body-mind suffered by an external or internal source of violence. Transforming violence into a "law," into a "making sense" and assuming the position assigned to you by that universe of meaning which accommodates the violence of one part of humanity over another to which you belong is what alienates you from your suffering and joy. The operation which enables the alienating operations of socio-economic repression is abstraction. The rule of abstraction finds its purest form in capitalism, in the universe of pure speculation as the source of material domination or absolute domination over the material.

The immanent rebellion François Laruelle writes about consists in "the struggle without a goal" always already present in every human (not the human subject but the real of human or, in Laruelle's vocabulary, "the human-in-human"). It is without a goal, because its only source and tendency is to protect itself from violence through alienation, to defend the human-in-human it is insofar as determined by radical vulnerability. Any political struggle stems from the dictate of the immanent rebellion determined in the way thus explained. The struggle is one of radical singularity which does not mean that it cannot establish solidarity or that it is individualistic. Quite to the contrary, it is pre-subjective whereas individualism presupposes subjectivity. The lived of vulnerability and struggle can be an experience of a collective and that experience can be mute, pre-lingual, radically solitary insofar as it is only the "witnesses" of the experience can 
communicate it internally according to the syntax of the real of what took place. The protestants of Istanbul in the summer of 2013 were faced with the challenge to formulate their political goals, convey the philosophical (=political) decision determining their struggle whereas the only truth they knew was that of "what took place" in Gezi park and the massive solidarity it sparked. The brutality Erdogan's government demonstrated was the reason for the issuing demand that he leaves office. Only thereof, they could define a political agenda which was still not philosophical , i.e., ideologically defined but one determined by concrete demands dictated by the concrete experienced reality. Revolt took place, struggle against institutionalized violence rose and the sheer experience of revolt-struggle proffered the foundation for the creation of a political agenda.

In order to clarify the stakes and the limits of rebellion we pose the problem outside of philosophical bad habits. Philosophy is always indifferent to man or, though this isn't very different, too quickly compassionate. Sufferings and alienation exist in the necessity of revolt and one concludes from this that there is evil, and often evils, there too. Revolts are only 'logical' in this way - admirable vicious circle of uncertainty and the contingency of a desired rebellion in which no one believes. ${ }^{1}$

It is necessary that the rebellion seems incredible. Credibility implies planned steps toward achieving a goal determined by a philosophical decision (about "what and how the world should be"). The resistance "to evils" is carried out from a vulnerable position and by those who are determined in the last instance by the sense of being "persecuted."

The theory of Future Christ makes of the being-murdered and the being-persecuted a universal but real criteria of the manifestation of Life rather than an absurd condition of historical fact. ${ }^{2}$

Life is conditioned by the sense of being persecuted and that brings forth immanence or inevitability of revolt and struggle. Persecution is by definition caused by "the world" which in Laruelle's terminology is analogous to philosophy - the universe of meaning. The universe of meaning is necessarily a universe of norm and of orthodoxy. The immanent struggle or the human-in-human determined by immanence of struggle is in revolt against the world and against orthodoxy as its foundation. The human in human in the last instance is a heretic. The world, on the other hand, seeks to control him and her by way of subjugating them by way of abstraction which controls, moulds, violates the lived (le vécu), as Laruelle terms it, and acts in its stead.

"[...] to struggle in an immanent way with the World, this is the theorem of the Future Christ. In the beginning was the struggle, and the struggle was with the World and the World did not know it ... That is rebellion, its reasons and cause." 3

\section{The World as Persecution}

"In human beings there is 'a something' of a radically outside-nature, and the World is a fundamental will that persecutes this heresy." (Laruelle, Future Christ, 19)

Nature is, of course, part of the world and a creation of orthodoxy. Or, putting it in Judith Butler's terms, nature is always already product of the imaginary upon whose edifice the Norm and "normality" are erected. The immanent rebellion is rooted in the realization about the lack of immanence in any norm and in the norm's coercive ruse of posturing as a law of nature or of society that conforms with nature as the underlying truth of all existence.

Man-in-person is not an empire within the empire of the World but is that from whom the Real takes precedent above those empires that persecute him and who, turning himself into a victim, confesses to his being-human in spite of them. By a decision of an axiomatic kind, we therefore place the protestations of rational sufficiency and the belief in philosophical and theological opinion between parentheses. We posit that the ethics of transcendence, as much as those of the immanence of the happy life, belong to the World, that the religions of the Book, just as the others, are religions of the death-World. ${ }^{4}$

\footnotetext{
1 François Laruelle, Future Christ: A Lesson in Heresy. Translated by Anthony Paul Smith (London: Continuum, 2010), 5-6

2 Ibid., 19.

3 Ibid., 4.

4 Ibid., 19
} 
Man-in-person or subjectivity affected by immanence is not a universe in its own right. The liberal myth of sanctity of the individual and its capacity to create its unique moral, political, esthetical universe-a "world" - is declared false. The only world we can be in and the only world we represent is the world in the sense of non-philosophy. The "world according to non-philosophy" is analogous to Lacan's symbolic order or Foucault's disciplining discourses of power. It is indeed formative of the subject, but the human in the last instance, according to Laruelle, is pre-subjective. It is the real of the radical vulnerability and immanent revolting. The inexhaustible force of revolt is not based in philosophy or in the world - it is situated in the radical opposition to it, it acts from the standpoint of the lived. The opposition to the world or to the ruling norms/normativity is radically static. It is atemporal and does not participate in the transformations of meaning the world produces. Nonetheless, it aspires to change the world in a way which will make it less brutal to the radical vulnerability the human in human is. Immanent rebellion is static in the double sense of the word, i.e., as "not moving," but also as in the sense of the Athenian political concept of stasis which means a rebellion or a civil war in the polis. Although stasis implies unrests it remains static vis-a-vis the world and stops the endless signification the world compulsively produces. It represents suspension of the polis. Stasis, meaning both stillness and

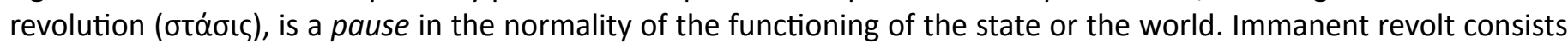
in the human-in-human's radical externality with respect to the unstoppable auto-generated processes of subjection (of "being a subject") in the world.

The world invades the mute lived (le vécu) of the human-in-human in the form of the installation called subjectivity. Meaning (sign), general and abstract, aims to shape the real, to produce joy and suffering according to the ruling forms of jouissance which are philosophically determined. The a priori invasiveness of the world makes the humanin-human always already persecuted. The only way to immanently revolt against the world is the non-abstract way. Revolting against concrete occurrences of subjugation and violence rather than in the name of abstractions and visions of transformation of the world is political action "affected by immanence." ${ }^{5} \mathrm{It}$ is also action determined by "interests" which are real and sensuous (or material), says Marx, rather than abstract or philosophical. As explained in the previous chapter, according to Marx, abstraction itself is what ought to be combated and a world in consonance with the real or the material immediate exigencies should be created. The world will be always made of philosophy, Laruelle would say, and it will always already persecute the human in human. The constant revolution can transform it into a socio-political order which is observant of the "real interests" rather than abstractions, writes Marx. In that way, the world could become a more just and happier place, one where persecution is minimalised by virtue of the reversal in hierarchy between philosophy and the real whereby the former would succumb to the dictate of the latter.

\title{
3. To be a victim and to be a messiah: radical humanity
}

\begin{abstract}
"The victim is defined by a radical passivity and not by an absolute one which Levinas attributes to the self. By definition, radical passivity cannot re-act through an excess of power or by overpowering, it is impossible for it to act in a reflexive manner, but it is capable of acting quite differently - by depotentializing philosophical overpowering." ${ }^{6}$
\end{abstract}

Revolt can grow immanently and also infinitely - because infinity is dictated by intensity and intensity is the mode of immanence - only if it undercuts philosophical pretension. Its power is passive since it is made of suffering. However, radical passivity is potent since it silences and cancels any philosophical decision regarding the suffering of the always already persecuted. Radical passivity and the revolt it engenders is a cry to all the masters of the world to cease their talk of the victims and of their liberation, to cease re-presenting them and alienating them through representation.

Philosophical representation is never generic. It is an abstraction whose origin is purely transcendental whereas the generic is a radical concept determined by the real and the "syntax of scientific description" it dictates (Laruelle Intriduciton au non-marxisme). In Théorie générale des victimes (2012), Laruelle explains the notion of the "generic" in the context of the study of victims and, par consequence, their revolt and the revolt of those who act in radical solidarity with them. "The generic," says Laruelle, "is a process of reduction of any philosophical or macroscopic entity, of its nature of a double, doubling, double transcendence (the consciences, the ego or a psycho-sociological identity). Reduction to a phenomenal immanence, one, however, lived as objective, subjected to the quantum principle of superposition is not a principle of a logical identity."

\footnotetext{
${ }_{5}^{5}$ François Laruelle, Introduction au non-marxisme (Paris: Presses Universitaires de France, 2000), 48.

${ }_{7}^{6}$ François Laruelle, Théorie générale des victimes (Paris: Fayard, 2012), 30.

7 Ibid.
} 
If we rid the concept of the victim of all its philosophical "essences," of all forms of representation which transform the lived suffering of the "victims" into pure transcendence (meanings of victimhood), we will do away with the representation and the images (produced through media) of the victims that act in the stead of the reality of being a "victim." The philosophically mediated idea of a victim, the one produced by the media and the intellectuals who represent and defend the victims, pretends to be the reality of the victims' suffering and one is interpellated to identify with these images and the meanings assigned to them. Considering the notions or "the world" and "philosophy" are synonymous in non-standard philosophy, the media are one of the most powerful and most active "machines" of the production of philosophical images (or of the ruling representations in and of the world which dictate our actions). The more they seek to be realistic the more detached from the real they are. They establish, what Laruelle terms, amphibology of the real and the philosophical (or the transcendental), whereby the latter acts instead of the former. Absurd is produced by the pretension that the "meaningful real" is more real than "just the real," the latter being deemed as the unruly effect of "meaningless" thrust of an almost physical symptom - tuché as Lacan would call it - into the universe of meaning.

In his General theory of the victims (2012) Laruelle invites us to establish a process of compassion (in its etymological sense) or co-suffering with the victims on the basis of a complete disregard of the mediation of victimhood by the "intellectuals" (and their world of the media). How do we accomplish this goal?

If we reduce the humanist human to a human without humanism-let's call it a non-human-or the instance of the real made of the lived of suffering (and joy), then what we are faced with in a victim in the last instance is the lived of suffering. To establish solidarity is to co-suffer by virtue of the rudimentary cognitive procedure of identification with the pain to which the other is subjected. One "imagines" the pain suffered by the other in a unilateral way - the pain invades the "imagination" of the co-sufferer which produces a "life-decreasing" effect (Spinoza). One imagines the fundamental and founding vulnerability of the other and of oneself, which is a procedure of identification. A process of abstraction only-cognitive and metaphysical/existential-can enable alienation from the other's suffering and failure to identify with it on the level of experience or in the form of co-experiencing. The tendency to establish compassion with "what it means to be a victim" or subject to inflicted pain or violence causing suffering, with the loss of "dignity" or "value" of the human life is a philosophical one. It always already alienates the real (the human in the last instance is). Co-suffering with the other's real and in terms of the real implies abandonment of (philosophical) humanism. It produces radically human sociality or, in Marx's terms, one in accordance with the interests of the "species" rather than abstract ideas of general humanity. ${ }^{8}$ Solidarity stems not solely from the lived co-suffering but also from the concomitant experience of "immanent revolt" or the "immanent struggle." Therefore, it is the lived of immanent revolt for the other's suffering as one's own that is the basis of solidarity or, rather, of radical solidarity inasmuch as solidarity in and for the "species" or for the "non-human" (the human without humanism). Suffering immanently produces revolt, whereas co-suffering gives rise to an immanent revolt-in-species or radical solidarity (of the "nonhuman"). Revolt-in-species is determined by Marx's concept of the human species as a hybrid formation of sociopolitical relations (forming a whole of the relations) and of nature or physiology. It is an idea of humanity as a social and biological factum without the abstractions of humanism. Therefore, the solidarity we establish with another human being understood in Marx's (but also Laruelle's) way is determined by biology as much as it is determined by the whole of heterogeneous and complex social relations. It is not driven by an idea of an essence of humanity incarnated in each human being.

Feuerbach resolves the essence of religion into the essence of man [menschliche Wesen $=$ 'human nature']. But the essence of man is no abstraction inherent in each single individual. In reality, it is the ensemble of the social relations. ${ }^{9}$

The human species is defined as species-among the animal species-and is, therefore, determined in the last instance by nature:

That man's physical and spiritual life is linked to nature means simply that nature is linked to itself, for man is a part of nature. ${ }^{10}$

\footnotetext{
8 Marx, Economic and Philosophical Manuscripts 1844 (Moscow: Progress Publishers, 1959). Theses on Feuerbach: The 6th Thesis, available at http://marxists.anu.edu.au/archive/marx/works/1845/theses/index.htm, accessed on 29 November 2013 ${ }^{9}$ Ibid.

10 Marr

Marx, Economic and Philosophical Manuscripts 1844: Estranged Labor, available at http://www.marxists.org/archive/marx/works/1844/ manuscripts/labour.htm, accessed on 29 November 2013.
} 
Solidarity is radically grounded in physicality. Namely, alienation - through objectificaiton of labor-deprives the human being of his/her labor and of "means of subsistence" provided by nature and, therefore, subjugates him/her by virtue of rendering him/her first a "worker" and then a "physical subject." Political solidarity and collective revolt are, in the last instance, about overcoming the alienation of the human animal from nature as the source of the means of subsistence and as the real universe of his/her labor. It is also about overcoming alienation from and within the human universe of social and political relations, but this process is also about the return to the real, to the material (without materialism) or to the "sensuous" human life and its relations to other beings, to nature and to the products of labor as part of nature or as non-alienated from it.

Man is directly a natural being. As a natural being and as a living natural being he is on the one hand endowed with natural powers, vital powers - he is an active natural being. These forces exist in him as tendencies and abilities - as instincts. On the other hand, as a natural, corporeal, sensuous objective being he is a suffering, conditioned and limited creature, like animals and plants. That is to say, the objects of his instincts exist outside him, as objects independent of him; yet these objects are objects that he needs - essential objects, indispensable to the manifestation and confirmation of his essential powers. To say that man is a corporeal, living, real, sensuous, objective being full of natural vigour is to say that he has real, sensuous objects as the object of his being or of his life, or that he can only express his life in real, sensuous objects. To be objective, natural and sensuous, and at the same time to have object, nature and sense outside oneself, or oneself to be object, nature and sense for a third party, is one and the same thing. ${ }^{11}$

Alienation can be overcome only in the last instance, and that instance is physicality, matter or the real of suffering and of "instincts." Emancipation from any form of oppression is emancipation from alienation which stems from abstraction. Abstraction is a philosophical procedure of creating an auto-referential "universe of meaning" detached from the real of human existence in order to objectify it, master it and exploit it. Subject to abstraction and subjects of alienation are not only the proletariat or the precariat, but also the exploiters in the capitalist as well as in any other era. Emancipation is possible only if we all "give up our abstractions" (Marx), and everyone is equally called upon doing so. All of us are in the last instance radically vulnerable pre-subjective identities that revolt against exploitation and violence. The messianic revolt and resistance should be directed against the subject positions that maintain alienation and use the means of abstraction to exploit, subjugate and alienate its species (as well as the other species).

Brutality of exploiting what Laruelle terms "the human-in-human" (the pre-subjective instance of the real or the instance of the lived the human in the last instance is) and inflicting pain on others or profit on exploitative violence is enabled only if the human being is objectified as labor and if nature is objectified as means of production and subsistence. Nature certainly provides subsistence, but alienation from it and within it occurs when objectified. Alienation's immediate result is violence, subjugation and exploitation (of all and everyone subject to alienation).

Thus, if the product of his labor, his labor objectified, is for him an alien, hostile, powerful object independent of him, then his position towards it is such that someone else is master of this object, someone who is alien, hostile, powerful, and independent of him. If he treats his own activity as an unfree activity, then he treats it as an activity performed in the service, under the dominion, the coercion, and the yoke of another man. ${ }^{12}$

Estrangement of labor, estrangement from one another within the species and with other species and, also, estrangement from oneself-appearing as objectifying oneself as labor force or as "abstract activity and a belly"13_can be overcome by the radical procedure of immanently correlating with the "site" of the real of suffering and joy which in the last instance is not an abstraction, i.e., the bodily or the "sensuousness" of the self. Recuperating the determination-in-the-last-instance of the human as the physical, material or bodily, or as one rooted in and ultimately determined by "nature" aims at realization of the human animal as a non-human or as a non-animal. In other words, the human species can transcend alienation-hence, oppression-only by radically grounding itself in its material or real humanity, one which precedes philosophy and, ultimately, language. The human can come to its fullest realization by succumbing to the immanence of human animality (human without humanism) and by way of following the syntax

\footnotetext{
${ }^{11}$ Marx, Economic and Philosophic Manuscripts 1844. Critique of Hegel's Philosophy in General, available at http://www.marxists.org/archive/ marx/works/1844/manuscripts/hegel.htm, accessed on 29 November 2013.

${ }^{12}$ Marx, Economic and Philosophical Manuscripts 1844: Estranged Labor, available at http://www.marxists.org/archive/marx/works/1844/ manuscripts/hegel.htm, accessed on 29 November 2013.

${ }^{13}$ Marx, Economic and Philosophical Manuscripts 1844 (Moscow: Progress Publishers, 1959), First Manuscript, available at http://www. marxists.org/archive/marx/works/1844/manuscripts/wages.htm, accessed on 29 November 2013.
} 
of the real it dictates in the processes of cognition and the metaphysics they prompt.

\section{Metaphysics in radical terms and as real necessity}

François Laruelle's book entitled Théorie des Etrangers: Science des hommes, démocratie et non-psychanalyse (1995) ${ }^{14}$ is a project of non-philosophical procedure of radicalizing Lacanian psychoanalysis to a "non-analysis." Namely, it aims to radicalize psychoanalysis by way of producing conceptual means for it to account for the workings of the instance of the real and its conditioning effects on the signifying processes. The real of the "human-in-human," according to Laruelle's non-analysis, inevitably mediates itself and the process is one of estranging oneself from the real one is. One has to transpose oneself into a lingually conceived self, into a subject in order to mediate the real (one is) to the others and to oneself. Prior to becoming a subject one becomes a "Stranger" which is "radical subjectivity." ${ }^{15}$ Unlike the subject which can emerge only as the result of a fully completed estrangement from the lived (the real) and which is a signifying position or virtually a sheer function (of the self), the Stranger is affected by the immanence of the process of estrangement. It is "concrete," made of transcendence (language) and in unilateral affirmation of the dyad consisted of the real and the transcendental (language). In its gesture of estrangement, the Stranger transcends the real while experiencing the process of estranging from the real he or she is (in the last instance) as lived. The real from which one alienates oneself is objectified, so that one can transcend the real one is. Thus, one transcends oneself, the self in the last instance or the self-in-the-real is rendered object of control and auto-production by the language and through the function of the linguistically competent subject.

The Stranger is still in the real (of estrangement) while the trauma of the primal metaphysical procedure takes place - that of "becoming stranger to oneself" or sensing the core of oneself as an exteriority. Laruelle insists the "concreteness" of the Stranger is not "empirico-metaphysical" but rather "transcendental." My claim is that this gesture is fundamentally metaphysical. Scientific thought is transcendental with respect to the unruly real. It creates designs, produces abstractions which aim to explain the real. The experience of estrangement is however existentially conditioning-or, in philosophical vocabulary, "ontological" - introducing "spectrality" of language or thought as inalienable element of the self. The paradox-which, non-philosophically speaking, is falsehood and does not exist-engenders the creature of religion, philosophy or science or the "human species" as the most metaphysical animal. (Other animals experience metaphysical states as well, as I have been convinced by Giorgio Agamben's treatise "The Open.") Wondering or $\theta \alpha \tilde{\mu} \mu \alpha$ over the necessity of the production of the spectral self and the world of spectrality, wondering if the real self is (in) the real itself or if the truth of it (what we make out of it as linguistic subjects) is more real (than the real devoid of meaning/truth) prompts metaphysics. When metaphysics conditions the physical to the extent that it perverts its "lifeincreasing" (Spinoza) impulses or the conatus of survival urging "life-decreasing" activities (such as alienated labor and fruits of that labor), that means that "a sufficient thought," viz. thought that usurps the status of the real, conditions the world. It conditions the world politico-economically as well as philosophically causing radical subjection and exploitation of the "real" or the "sensuous" (Marx). By objectifying the "material" (without philosophical materialism), absolute abstraction has effaced any trace of the experience of estrangement as immanent and has committed the perfect crime against the real (Baudrillard) convincing the world that it (abstraction) has always been the only real that ever existed. According to this logic, the "senseless real" is not real. What makes sense and what is real have been equated.

In non-philosophy, the equation at issue is called "decisionism" which is what defines philosophy. This is a defining trait of any and all philosophy. Namely, it decides a priori what the real is, and, according to this grounding definition only, all further investigations of the real and of different realities are carried out. Scientific approach, both according to Laruelle and Marx, permits that thought is always "surprised" by the real, and that gaps and inconsistencies in a system of thought are permitted and, moreover, invited and unavoidable since thought succumbs to the "real" rather than to the "real's meaning." Therefore, the transcendental-which is the substance of any form of thought-is also the material scientific thought is made of. The necessary procedure of estrangement is, however, metaphysical.

Metaphysical is the effect of the necessary procedure of estrangement, of the unavoidability to create the spectral doublet of the physical self and to transcend physicality in the form of re-creating oneself as an idea of oneself. To paraphrase Lacan, the mirror image of the self tends to occupy the position of the real self. It is endowed with the ambition to become more "real than the real." In this sense, it is identical with the tendencies of philosophy. Nonetheless, the primary metaphysical experience takes place in the mist of the vagueness of concept and physicality of the real. The subject constituting process of estrangement is a sensation, it involves physicality and intense mental

$\overline{14}$ François Laruelle, Théorie des Etrangers: Science des hommes, démocratie et non-psychanalyse (Paris: Éditions Kimé, 1995).

15 Ibid., 196 
experience which precedes pure concept while nonetheless represents a process of conceptualization. This process is what Laruelle would call an instance of the lived (vécu) rather than an exclusively intellectual procedure, which follows the laws of logic and discipline of maintaining a consistent "universe of meaning." Although it seeks to establish control over the real, it also seeks to "fill" the spectral self with it or for the real to legitimize the idea of the self. It seeks not to find itself and to remain in the fissure of the split between idea-(of)-self and the real, and it seeks to do so by ensuring the real will "legitimize" the idea by finding itself at home with or in it.

Philosophy enters the scene when meaning seeks to legitimize the real upon the basis of radical detachment and indifference to it; even the reverse direction of inter-legitimization, in the last instance, consists in the same gesture: by claiming that the real is reflected by thought in its totality, one produces a reality that should act in the stead of the real (as a more perfect real than the real itself). Concurring with Laruelle, let us say that the equation established between thought and the real is the essential procedure of philosophy, i.e., of its decisionism. It presupposes overcoming of the anxiety produced by the real seemingly splitting into two when the idea of the self emerges as a reality in its own right. As for the metaphysical-in the sense I am using the word here-it struggles with the real and the possibility of detachment of the "spectral self" from the real is an experience of anxiety, of pain and of pleasure. In the last instance, it is an experience, it is a pure instance of the lived (Laruelle) or of the real, albeit involving operations of the transcendental, i.e., the mental processes of duplication of the real.

Those processes of alienation that are foundational for the subject create a metaphysical drama which determines grand ideologies, universes of meaning (philosophies, political and economic contracts) as much as the human species' "being-before-death" or sexuality. Alienation is the operation which is conditional for the possibility of exploitation, it enables the severing from the "state of innocence" in which the naive and radical human is in awe of the real (of) life so that the possibility of objectifying the real of the other living beings or of oneself is inconceivable. The procedure of objectification is indispensible and it is enabled by the operation of alienation from oneself, from the others, from the "sensuous life" (Marx), from the real. Only by virtue of absolute alienation which brings about absolute abstraction and only by abstraction's usurpation of the position of the real (as the "most perfect real") has the criminal rule of capitalism been inaugurated and is maintained. Such process is impossible without the immanently philosophical operation of "gradation of the real," according to which the truer a reality is "the more real" it is. What is specific of capitalism and modernity is the fact that, unlike in the premodern times when the "most real reality" was somewhere else, in a different universe ("the world of ideas", the Kingdom of God), the "ever perfecting real" occupies the material space and the temporality of the human. Thus it is a sheer operation, it is a methodological procedure, it is a ruse. It does not believe in the possibility of a better and more perfect universe but only in the intellectual trick which constitutes a reality in its own right. It simulates the material reality, it also operates with it and is concerned only with it but only in order to "spectralize" and accomplish its total exploitation. The materialism of the contemporary capitalist society is deprived of a sense of realness, since the real is replaced by operations of abstraction made of the meanings we have assigned to the real and to materiality. Capitalist and modern philosophy's materialism is about the unstoppable tendency-since it is an immanent tendency-to transpose "sensuous matter" into the meanings that can be attached to it and thereof be reduced them. Perversely, it's materialism without matter. The ruse of abstraction has mathematized matter and body, transformed economy into finances and sensations into psychological phenomena subject to biopolitical control. To speculate with resources, with lives, has brought about the rule of absolute speculation: management of realities and financial speculations as economy.

The political task of greatest urgency today is to emancipate the radically metaphysical and the "sensuous life" (the material without materialism and the real without philosophical realism) from the rule of abstraction. This is the core of Marx's call for emancipation of the "human species." And this call has never been answered through any other means except philosophical. "Dialectical materialism" is philosophically sufficient, put in Laruellian terms. Namely, it is a sufficient principle to determine and decide what is real. Not to betray this principle-not to betray principles of the doctrine-has become more important than not betray the real which invites the doctrine to examine its tenets. Abstraction has ruled Marxism - and Marxism has ruled through abstraction-for more than a century. Communist parties and states of the 20th century, in spite of the numerous differences, had one thing in common - the real, material, sensuous human life was the objectifiable material and means that served the greater political goals: "The perfect political state is, by its nature, man's species-life, as opposed to his material life." ${ }^{\prime 6}$

If "giving up one's abstractions" (Marx) is the central and most important task of the science Marx invents and attempts to institute, then the task is to emancipate the necessary and primitive metaphysics of mediating the immediate real.

${ }^{16}$ Karl Marx, Works of Karl Marx 1844: On the Jewish Question, available at http://www.marxists.org/archive/marx/works/1844/jewishquestion/, accessed on 29 November 2013. 
Economic emancipation and other important forms of social emancipation would only follow consequentially. The first task is to overcome the underlying alienation enabling the dichotomy between state politics and the civil society, between the "spiritual" or religion and the secular and, finally, to overcome phantomal existence and its suffocation of "real life."

The perfect political state is, by its nature, man's species-life, as opposed to his material life. All the preconditions of this egoistic life continue to exist in civil society outside the sphere of the state, but as qualities of civil society. Where the political state has attained its true development, man - not only in thought, in consciousness, but in reality, in life - leads a twofold life, a heavenly and an earthly life: life in the political community, in which he considers himself a communal being, and life in civil society, in which he acts as a private individual, regards other men as a means, degrades himself into a means, and becomes the plaything of alien powers. The relation of the political state to civil society is just as spiritual as the relations of heaven to earth. The political state stands in the same opposition to civil society, and it prevails over the latter in the same way as religion prevails over the narrowness of the secular world - i.e., by likewise having always to acknowledge it, to restore it, and allow itself to be dominated by it. In his most immediate reality, in civil society, man is a secular being. Here, where he regards himself as a real individual, and is so regarded by others, he is a fictitious phenomenon. In the state, on the other hand, where man is regarded as a species-being, he is the imaginary member of an illusory sovereignty, is deprived of his real individual life and endowed with an unreal universality. ${ }^{17}$

Instead of simply concluding with this quote by Marx, let us remind ourselves: So far, both the bourgeois and the communist regimes have managed to maintain and deepen these divisions. They have accomplished this through the absolute rule of abstraction and brutal subjugation of materiality.

Katerina Kolozova is professor of philosophy and feminism at the Institute of Social Sciences and Humanities Skopje. She is the author of The Cut of the Real, forthcoming with Columbia University Press in January 2014.

17 Karl Marx, Ibid. 